\title{
Protein and iron contents and bio accessibility in local modified diets for children aged 6 to 23 months in Bukoba, Tanzania
}

\author{
${ }^{*}$ Mbela Domina Esther Nkuba ${ }^{1 / 2}$, Kinabo Joyce ${ }^{2}$ Mwanri Akwilina Wendelin $^{2}$ and Ekesa \\ Beatrice $^{3}$ \\ ${ }^{1}$ Mikocheni Agricultural Research Institute, PO Box 6226 Dar es Salaam, Tanzania \\ ${ }^{2}$ Sokoine University of Agriculture, Department of Food Technology Nutrition and Consumer Sciences, PO Box 3006, \\ Morogoro, Tanzania \\ ${ }^{3}$ Bioversity International, Plot 106, Katalima Road, P.O. Box 24384, Kampala, Uganda \\ *Corresponding author Email: dominankuba@yahoo.com or dominankuba2013@gmail.com, +255754749382, Tel.
} +255-22 2700552 Fax: 255-222-775549

\section{ABSTRACT}

\begin{abstract}
Micronutrient deficiencies often occur as part of a cycle of malnutrition and may be coupled with protein energy malnutrition. One of the measure to fight malnutrition is through participatory dietary modification was used. Five recipes of banana-based porridges from two EAHB 'nshakala' and AAB 'bira' banana varieties and three maize-based porridges were formulated in combination with other ingredients. The contents of Iron and protein in separate ingredients and in modified recipes were analysed using flame atomic absorption spectrophotometry and Kjeldahl's method, respectively, and bio-accessibility of iron was estimated using invitro simulating gastrointestinal digestion method. Beans were a good source of both iron and protein while groundnuts flour was a good source of protein. Contribution of iron and protein in recommended daily allowance (RDA) ranged from 75.3 to $458 \%$ and 106 to $146 \%$ in a portion of $500 \mathrm{~g}$ respectively. Iron bioaccessibility in all recipes ranged from $7.4 \%$ to $31.1 \%$. Iron in porridge recipes (6OFSP, 7B) was more bio-accessible. The developed and improved recipes showed great potential of contributing substantially to iron and protein needs of children 6-23 months. The importance of food diversification for intake of iron and protein is discussed.
\end{abstract}

Key words: Diet modification, children below five years, protein, iron bioaccessibility

\section{INTRODUCTION}

Micronutrient and protein deficiencies are a global public health concern (Detzel and Wieser, 2015; NBS, 2016). Globally, pregnant women and their children below five years are at the highest risk of micronutrient deficiencies (Bailey et al., 2015). Iron is an essential micronutrient for the immune system and critical for optimal growth and cognitive function (Bailey et al., 2015; NBS, 2016).

Bioavailability is the fraction of an ingested nutrient that is available for utilization in normal physiological functions and/or for storage (Etcheverry et al., 2012). Of the two forms of iron: heme from animal sources and non-heme from plant source. Neither form is highly bioavailable by the body. The bioavailability heme-iron is estimated to be 12 to $25 \%$ while the non-heme iron is $5 \%$ (Bailey et al., 2015; Trumbo et al., 2001). On the other hand, bio accessibility is the amount of nutrient released from the food matrix and accessible for absorption (i.e. the transfer into micelles) (Etcheverry et al., 2012; van Lieshout et al., 2001).

Iron deficiency anaemia (IDA) is mainly due to iron deficiency. IDA affects over two billion people worldwide and 190 million preschool-age children (Bailey et al., 2015; Detzel and Wieser, 2015). Iron deficiency affects $60 \%$ of children below five years In Tanzania and $58 \%$ of 
Table 1. Food recipes and their ingredients used in the study

\begin{tabular}{|c|c|c|}
\hline Recipe name & Recipe code & Ingredients in the recipe \\
\hline $\begin{array}{l}\text { Banana purée 'Nshakala' dry } \\
\text { bean }\end{array}$ & $1 \mathrm{~N}$ & EAHB 'nshakala' variety, dry red kidney beans, amaranths, palm oil, salt, onion, tomatoes, bitter tomatoes \\
\hline $\begin{array}{l}\text { Banana purée 'Nshakala' } \\
\text { fresh bean }\end{array}$ & $2 \mathrm{~N}$ & EAHB 'nshakala' variety, fresh red kidney beans, pumpkin leaves, sunflower oil, salt, onion, tomatoes, bitter tomatoes \\
\hline $\begin{array}{l}\text { Banana purée 'Bira' dry bean } \\
\text { Banana purée 'Bira' fresh } \\
\text { bean }\end{array}$ & 4B & $\begin{array}{l}\text { AAB 'bira' variety, dry red kidney beans, amaranths, palm oil, salt, onion, tomatoes, bitter tomatoes } \\
\text { AAB 'bira' variety, fresh red kidney beans, pumpkin leaves, sunflower oil, salt, onion, tomatoes, bitter tomatoes }\end{array}$ \\
\hline $\begin{array}{l}\text { 'Katogo'/'matoke' katogo'or } \\
\text { 'matoke' is a local recipe } \\
\text { prepared from banana, beans } \\
\text { and other ingredients }\end{array}$ & $5 \mathrm{~N}$ & \\
\hline purée & & EAHB 'nshakala' variety, pumpkin fruit, groundnuts flour, salt, onion, tomatoes, bitter tomatoes \\
\hline $\begin{array}{l}\text { Orange-fleshed sweet potato } \\
\text { porridge }\end{array}$ & 6OFSP & Fermented maize flour, orange fleshed sweet potatoes, groundnut flour, sugar \\
\hline 'Bira' porridge & 7B & Fermented maize, AAB 'bira' variety, groundnut flour, sugar \\
\hline Egg porridge & $8 \mathrm{E}$ & Fermented maize flour, egg, red kidney beans, sugar \\
\hline
\end{tabular}

them are anaemic (NBS, 2016). In Kagera 25\% of children suffered iron deficiency and $49 \%$ of them are anaemic; (NBS, 2011). Protein energy malnutrition (PEM) occurs when the body requirements for protein or energy or both cannot be met through diets. Similarly, micronutrient deficiencies often occur as part of a cycle of malnutrition and may be coupled with protein or energy malnutrition (Bailey et al., 2015). Prolonged PEM can cause irreversible changes in organ function and growth; delayed and irreversible cognitive development (Klein, 2012). Children are at increased risk for protein and iron deficiencies when introduced to complementary foods, which are usually made of starchy-staple such as banana, cereal or root and tuber crops with little or no fruit and vegetable or animal source of protein and iron (Christides et al., 2015; Kennedy et al., 2010;). These starchy-staple foods are often poor dietary sources of iron as they contain high levels of iron absorption inhibitors such as phytates (Amagloh and Coad,
2014; Saunders, et al., 2012; Soetan and Oyewole, 2009). One of the methods to prevent micronutrient deficiencies is dietary modification. These deficiencies can be addressed by consumption of animal and plant based foods, but animal sources are expensive compared to plant sources (Bailey et al., 2015). Godson, 2014 reported that in Bukoba district, local diets for children prepared with banana and beans were low in iron content $(1.18 \mathrm{mg} / 100 \mathrm{~g})$. According to Kennedy et al.. (2010) a modified diet is any diet altered by nutritionist or dietician to include or exclude certain components, such as vitamins, minerals, protein, calories and fat, mainly using the available local types of foods. Information on the nutrient content of foods commonly consumed in rural communities of Tanzania is limited (Kinabo et al., 2006). The present study analysed iron and protein contents and iron bio-accessibility in order to enhance their intake to children aged 6-23 months using modified local diets mostly from plant sources that are affordable to smallholder farmers.

\section{MATERIALS AND METHODS}

Eight food recipes were modified to enhance intake of iron and protein to children below five years (Table 1). Five recipes were banana-based from 'nshakala', Nshakala' is East African Hybrid Banana (EAHB) local variety and AAB 'bira" 'Bira' is triploid hybrid of Musa acuminata and Musa balbisiana (AAB) banana varieties, and three maize-based porridges. To improve nutrient and spontaneous fermentation (using the microorganisms that are naturally present in food) was done to ferment maize flour for 24 hours fermentation to reduce phytic acid in cereals and legumes to enhance the content of micronutrients and improve micronutrient bio accessibility (Berhanu et al., 2014; Gibson and 
164 Afr. J. Food Sci. Technol.

Hotz, 2001; Mbela et al., 2017-in press).

\section{Study Area}

The study was conducted in Izimbya ward of Bukoba district in Kagera region Tanzania. The region is located in the North-western Tanzania, west of Lake Victoria. The main farming system in the study area is banana-farming system integrated with coffee and other annual crops such as beans, maize, sweetpotato and yams.

\section{Sample Preparation and Processing}

Food ingredients (Table 1) were purchased from the local market at Izimbya ward in Bukoba district. They were properly packaged in an aerated carton and air-freight to the department Food Science and Biotechnology at BOKU University in Vienna, Austria for laboratory analysis. Triploid hybrid of Musa acuminata and Musa balbisiana (AAB) 'bira' variety were obtained from neighbouring country, Burundi, because no mature fruit bunches were available in Tanzania. The banana varieties were transported on the morning of the harvest from Burundi to Kampala, Uganda where they were airfreight to Vienna, Austria within 48hrs of harvest.

On arrival at the department, all food samples were stored in a room maintained at $4 \mathrm{oC}$ until analysis. Recipes were prepared and cooked at the department laboratory according to the already defined procedures (Mbela et al., 2017-In press). All food samples were freeze-dried (lyophilized). Lyophilized foods were homogenized to a fine powder by grinding in mortar and pestle and later stored in sealed tubes in the dark at-24. $\mathrm{C}$ until analysis and in vitro digestion were carried out. All the food samples were analysed in triplicates for protein and iron contents and iron bio accessibility.

\section{Determination of Protein Contents of the Modified Recipes for Children Aged 6-23 months using Kjeldahl's method}

\section{Analysis of Protein Content}

Catalyst mixture of $7.5 \mathrm{~g}$ containing $(4 \mathrm{~g}$ of copper sulphate per $1 \mathrm{~kg}$ potassium sulphate) and some glass beads were filled in a digestion tube to avoid boiling retardation. The original sample weight was dependant on the expected protein content. Food samples were weighed into a digestion tube and $15 \mathrm{ml}$ sulphuric acid (H2SO4) was added. Digestion was done at different temperature regimes starting at $150^{\circ} \mathrm{C}$ for $15 \mathrm{~min}, 25^{\circ} \mathrm{C}$ for $15 \mathrm{~min}, 380^{\circ} \mathrm{C}$ for $60 \mathrm{~min}$ and $420^{\circ} \mathrm{C}$ for $90 \mathrm{~min}$. Then the digestion tubes were water cooled for about half an hour then $60 \mathrm{ml}$ ultra high quality water was added. The digestion tubes were added with $20 \mathrm{ml}$ boric acid (2\%) and $50 \mathrm{ml} \mathrm{NaOH} \mathrm{(32 \% )} \mathrm{and} \mathrm{distilled}$ for 3 min at steam distilling unit. After distillation, titration was done with $0.1 \mathrm{M} \mathrm{HCl}$ until the end point of $\mathrm{pH} 4.7$ (McClements, 2003). After decomposition nitrogen was available as ammonium sulfate and the flasks were connected to a VELP Automatic Distillation unit.

During distillation step ammonium sulfate was converted to ammonia by the addition of sodium hydroxide $(\mathrm{NaOH})$. The volatile ammonia gas moves to another flask containing boric acid (2\%). A chemical reaction leads to the conversion of ammonia to ammonium ion and boric acid to the borate ion, respectively. Nitrogen content was established by titrating the formed ammonium borate with $0.1 \mathrm{M}$ hydrochloric acid. The amount of hydrochloric acid used for the titration was used for the calculation of the nitrogen content and following total protein content (McClements, 2003).

\section{Protein calculation}

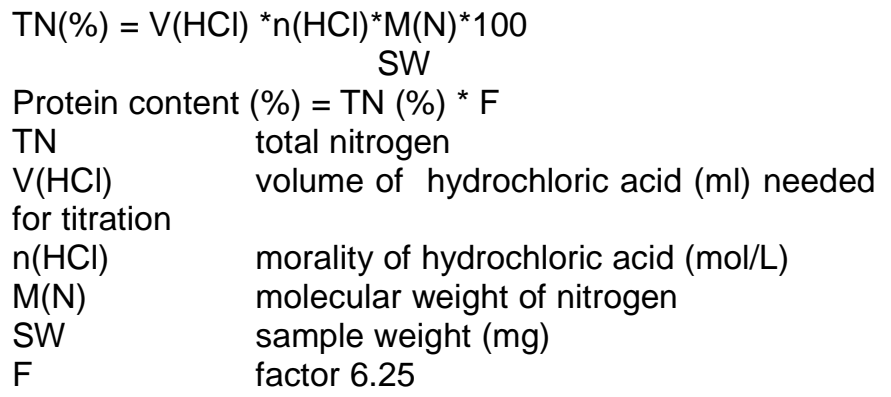

\section{Determination of Iron $(\mathrm{Fe})$ Contents of the Modified Recipes for Children Aged 6-23 months}

\section{Iron Content Analysis}

Determination of iron content of all freeze-dried samples was achieved through microwave digestion followed by a flame atomic absorption spectroscopy (FAAS). To analyze the iron concentration in the FAAS, sample solutions were transformed into aerosols and passed through the flame, which vaporizes and atomizes the sample. This step leads to a reduced intensity of the light (by absorption of a defined quantity of energy), coming from a hollow-cathode lamp. The detector measured how much of the incoming light was absorbed. Iron concentration is calculated from the difference between the radiation without sample and with sample (absorbance).

\section{Digestion of Freeze-dried food samples}

For each freeze-dried sample, $0.5 \mathrm{~g}$ of was weighed in a 
Nkuba et al. 165

Table 2. Mean Iron and Protein Content in 100g in Sample Weight of Raw Ingredients

\begin{tabular}{lll}
\hline Raw ingredients & $\begin{array}{l}\text { Iron } \\
\text { mg/100gfw (SD) }\end{array}$ & $\begin{array}{l}\text { Protein } \\
\mathbf{g} / \mathbf{1 0 0 g} \text { (SD) }\end{array}$ \\
\hline Orange fleshed sweet potatoes & $2.1(0.0)$ & $2.6(0.0)$ \\
Pumpkin fruit & $2.3(0.0)$ & $1.4(0.0)$ \\
Amaranths & $3.6(0.0)$ & $5.7(0.0)$ \\
Pumpkin leaves & $3.3(0.0)$ & $6.3(0.6)$ \\
Fresh red kidney beans & $6.9(0.0)$ & $11.9(0.4)$ \\
Dry red kidney beans, & $6.5(0.1)$ & $22.8(0.4)$ \\
Bitter tomato ('entongo) & $3.2(0.2)$ & $1.3(0.0)$ \\
EAHB ('nshakala' variety) & $0.9(0.0)$ & $1.1(0.0)$ \\
AAB ('bira' variety) & $0.7(0.0)$ & $0.9(0.0)$ \\
Tomatoes & $3.7(0.0)$ & $1.0(0.5)$ \\
Groundnuts flour & $1.9(0.1)$ & $27.5(0.2)$ \\
Fermented maize flour & $2.1(0.0)$ & $8.2(0.0)$ \\
Egg & $9.0(0.0)$ & $13.3(0.1)$ \\
Onions & $4.9(0.2)$ & $1.5(0.0)$ \\
\hline
\end{tabular}

${ }^{*} \mathrm{fw}=$ Fresh weight; $S D=$ Standard deviation

Teflon vessel and added with $5 \mathrm{ml}$ of $69 \% \mathrm{HNO} 3$ and $1 \mathrm{ml}$ of $30 \% \mathrm{H} 2 \mathrm{O} 2$. Vessels were closed, surrounded by high pressure safety coats (red or fluorescent dyes to aid in visual leak detection), put into rotor segments inside microwave and heated using the following program: 34 $\min$ heating $\left(10 \mathrm{~min} / 1000 \mathrm{~W} / 160^{\circ} \mathrm{C}, 4 \mathrm{~min} / 1000\right.$ $\mathrm{W} / 190^{\circ} \mathrm{C}, 20 \mathrm{~min} / 700 \mathrm{~W} / 190^{\circ} \mathrm{C}$ ) followed by $30 \mathrm{~min}$ cooling. Teflon vessels were removed from the microwave and opened to let the nitrogen oxides volatilize. The digested liquid samples were transferred into $50 \mathrm{ml}$ volumetric flasks. The vessels and breeches were rinsed with bi-distilled water three times. The flasks were filled up with water until the mark $(50 \mathrm{mls})$, shaken well several time and filtered through a paper filter ( $\mathrm{MN}$ 619 eh, Macherey-Nagel).

\section{Measurement of Iron content}

Preparation of calibration curve was prepared by diluting iron standard to 4 different concentrations: $0.04 \mathrm{mg} / \mathrm{L}$; $0.1 \mathrm{mg} / \mathrm{L} ; 0.5 \mathrm{mg} / \mathrm{L} ; 1 \mathrm{mg} / \mathrm{L} \mathrm{Fe}$. A blank value, consisting of $3 \% \mathrm{HNO} 3$ was prepared. To avoid masking of iron, $250 \mu \mathrm{l}$ of a $5 \% \mathrm{CaCl} 2$ buffer was added to $10 \mathrm{ml}$ of each food sample, standard and the blank value. The tubes were closed, mixed and briefly vortexed. The AAS measurement started with the analysis of the blank value, followed by the standards and the samples. Basing on the calibration curve and the specific absorption of the different samples, the AAS calculates the iron concentration of each sample. Concentration values were used for the calculation of the total iron content. By measuring the amount of absorption, the concentration of the analyte were calculated using the Beer-Lambert law; where $A$ is the absorbance, $\varepsilon$ is the wavelengthdependent molar absorptivity coefficient and $b$ is the path length. The sample concentration was calculated as follows:

\section{Iron Bio accessibility of the modified diets for children aged 6-23 months}

\section{In vitro digestion of iron}

The invitro digestion model was based on (Luten et al., 1989) with slight modifications in this study. In a $150 \mathrm{ml}$ flask, $5 \mathrm{~g}$ of each freeze-dried food samples were weighed and $80 \mathrm{ml}$ ultrapure water was added. To simulate gastric digestion $\mathrm{pH}$ of gastric digest was adjusted to $\mathrm{pH} 2.0$ with $6 \mathrm{M} \mathrm{HCl}$, controlled after $15 \mathrm{~min}$ and readjusted if necessary. Then $3 \mathrm{ml}$ of a pepsin solution $(16 \mathrm{~g} / 100 \mathrm{ml} 0.1 \mathrm{M} \mathrm{HCl})$ were added to the gastric digest and made to volume of $100 \mathrm{ml}$ with ultrapure water. The mixture was mixed and incubated for 2 hours at $37{ }^{\circ} \mathrm{C}$ at a shaking apparatus at $200 \mathrm{rpm}$ (Luten et al., 1989). The gastric digests were cooled to stop enzyme activity. Subsequently, $20 \mathrm{ml}$ of the gastric digest were removed and taken to another flask. Then, $5 \mathrm{ml}$ of a pancreatin mixture (4g pancreatin and $25 \mathrm{~g}$ bile extracts $/ 1000 \mathrm{ml} 0.1 \mathrm{M} \mathrm{NaHCO} 3$ ) were added. The $\mathrm{pH}$ was measured and adjusted to $\mathrm{pH} 7.5$ with $0.5 \mathrm{M} \mathrm{NaOH}$ and it was checked after 15 min and readjusted if necessary. (Luten et al., 1989). To stimulate intestinal digestion $20 \mathrm{ml}$ of the gastric digests were put into flasks. Dialysis tubings (molecular weight cut-off of $6000-8000$ $\mathrm{Da}$; flat width: $32 \mathrm{~mm}$; wall thickness: $30 \mu \mathrm{m}$; $\Phi$ dry: $20.4 \mathrm{~mm}$ ) were soaked in water for at least $15 \mathrm{~min}$ prior to use. Dialysis tubing containing $\mathrm{NaHCO}_{3}$ (in moles equivalent to the $\mathrm{NaOH}$ used to identify titratable acidity) diluted in $25 \mathrm{ml}$ ultrapure water was added to the digest and incubated for $30 \mathrm{~min}$ in the shaking apparatus at $37{ }^{\circ} \mathrm{C}$ and $200 \mathrm{rpm}$. The length of the tubing was set at approximately $20 \mathrm{~cm}$ from clamp to clamp (Luten et al., 1996). The sodium bicarbonate buffer diffuses slowly out of the tubing and neutralizes the digest (Etcheverry et al., 2012). Next, $5 \mathrm{ml}$ of the pancreatin/bile extracts mixture 
166 Afr. J. Food Sci. Technol.

Table 3. Mean Iron and Protein Contents and iron bioaccessibility (in 100g of edible portion) in the Modified foods for Children Aged 6-23 months in Bukoba Rural

\begin{tabular}{|c|c|c|c|c|}
\hline Recipe code & Modified Food Recipes & $\begin{array}{l}\text { Protein } \\
\mathrm{g} / \mathbf{1 0 0 g}(\mathrm{SD})\end{array}$ & Iron mg/100gfw (SD) & $\begin{array}{l}\text { Iron Bio accessibility } \\
\% / 100 \mathrm{~g}(\mathrm{SD})\end{array}$ \\
\hline $1 \mathrm{~N}$ & $\begin{array}{l}\text { Banana puree: 'Nshakala', dry red kidney beans, amaranths, palm oil, salt, } \\
\text { onion, tomatoes, bitter tomatoes }(1 \mathrm{~N})\end{array}$ & $3.4(0.1)$ & $9.1(0.1)$ & $7.9(0.2)$ \\
\hline $2 \mathrm{~N}$ & $\begin{array}{l}\text { Banana puree: 'Nshakala', fresh red kidney beans, pumpkin leaves, sunflower } \\
\text { oil, salt, onion, tomatoes, bitter tomatoes }(2 \mathrm{~N})\end{array}$ & $2.8(1.0)$ & $6.1(0.3)$ & $12.2(0.9)$ \\
\hline 3B & $\begin{array}{l}\text { Banana puree: 'Bira', dry red kidney beans, amaranths, palm oil, salt, onion, } \\
\text { tomatoes, bitter tomatoes (3B) }\end{array}$ & $3.3(0.1)$ & $9.0(0.1)$ & $7.4(0.2)$ \\
\hline 4B & $\begin{array}{l}\text { Banana puree: 'Bira', fresh red kidney beans, pumpkin leaves, sunflower oil, } \\
\text { salt, onion, tomatoes, bitter tomatoes (4B) }\end{array}$ & $2.8(0.9)$ & $5.8(0.3)$ & $11.1(1.5)$ \\
\hline $5 N$ & $\begin{array}{l}\text { Katogo: 'Nshakala', pumpkin, groundnuts flour, salt, onion, tomatoes, bitter } \\
\text { tomatoes }(5 \mathrm{~N})\end{array}$ & $3.8(0.2)$ & $1.9(0.1)$ & $26.7(1.4)$ \\
\hline 6OFSP & $\begin{array}{l}\text { Porridge: Fermented maize flour, orange fleshed sweet potatoes, groundnut } \\
\text { flour, sugar ( } 6 \text { OFSP) }\end{array}$ & $3.7(0.1)$ & $1.6(0.2)$ & $31.1(2.3)$ \\
\hline 7B & Porridge: Fermented maize, ‘bira', groundnut flour, sugar (7B) & $3.5(0.4)$ & $1.5(0.2)$ & 25.6(1.1) \\
\hline \multirow[t]{2}{*}{$8 \mathrm{E}$} & Porridge: Fermented maize flour, egg, red kidney beans, sugar (8E) & $3.0(0.4)$ & $3.5(0.1)$ & $12.7(0.5)$ \\
\hline & $\mathrm{p} \leq 0.05$ & & & \\
\hline
\end{tabular}

$\mathrm{SD}=$ Standard deviation

were added and the digests were incubated again for 2 hours (Luten et al., 1996). At the end of simulated gastrointestinal digestion the liquid inside the tubing contains iron represents the bioaccessible fraction of the element. The dialysates were transferred into plastic tubes. Then $15 \mathrm{ml}$ from the dialysates were transferred into centrifugation tubes and added with $800 \mu$ l of $69 \%$ HNO3 followed by centrifugation for $10 \mathrm{~min}$ at $10^{\circ} \mathrm{C}$ and $11,000 \mathrm{rpm}$. The supernatant was filtered through a paper filter. To determine the bioaccessible fraction of iron, filtered supernatant were measured using AAS and bioaccessibility was calculated as follows:

(Gautam et al., 2010).

\section{Statistical analysis}

Statistical analyses were performed using GenStat 14th Edition software. Mean were separated by Turkey mean separation test using Least Significant Differences (LSD) at $p \leq 0.05$. Determination of the significant difference between food samples using $p$-values was obtained by homogenous sets. Differences in mean content of total and individual protein and iron were observed following analysis and were tested using One Way analysis of Variance (ANOVA).

\section{RESULTS}

\section{Iron and Protein Content in Raw Food ingredients} used in Modified food recipes

Egg had more iron content with $9.0 \mathrm{mg} / 100 \mathrm{gfw}$ followed by fresh red kidney beans with $6.9 \mathrm{mg} / 100 \mathrm{gfw}$ and red kidney beans with $6.5 \mathrm{mg} / 100 \mathrm{gfw}$. Of all recipes groundnuts flour showed higher source of protein $(27.5 \mathrm{~g} / 100 \mathrm{~g})$ than dry red kidney bean $(22.8 \mathrm{~g} / 100 \mathrm{~g})$ and egg (13.3g/100g) (Table 2).

Iron and Protein Content in the Modified Diet and Recommended Daily Allowances (RDA) of Children Aged 6-23 months

The mean iron content in the modified recipes range from 1.5 to $9.1 \mathrm{mg} / 100 \mathrm{~g}$, with recipe $1 \mathrm{~N}$ showing the highest mean iron content of $9.1 \mathrm{mg} / 100 \mathrm{~g}$ and recipe $7 \mathrm{~B}$ having the least mean Iron content. These mean represent 6-fold variation. Mean protein contents ranged from $2.8 \mathrm{~g} / 100 \mathrm{~g}$ to $3.8 \mathrm{~g} / 100 \mathrm{~g}$, with recipe $5 \mathrm{~N}$ having the highest protein content of $3.8 \mathrm{~g} / 100 \mathrm{~g}$ followed by porridge recipe 6 OFSP $(3.7 \mathrm{~g} / 100 \mathrm{~g})$ and the least was $2 \mathrm{~N}(2.8 \mathrm{~g} / 100 \mathrm{~g})$ (Table 3$)$.

\section{Bio accessibility of Iron in the Modified Recipes for Children Aged 6 to 23 months}

The bio accessibility of iron in all recipes ranged from $7.4 \%$ to $31.1 \%$. Iron in porridge recipes were more bio accessible than in banana recipes. Recipe 6OFSP had high bio accessibility percent followed by recipe $5 \mathrm{~N}$ and $7 \mathrm{~B}$ with bioaccessibility of $31.1 \%, 26.7 \%$ and $25.6 \%$, respectively (Table 3). There was significant difference between 
Nkuba et al. 167

Table 4. Means of protein and iron content in the 8 modified recipes at $p \leq 0.05$

\begin{tabular}{llllll}
\hline \multicolumn{2}{l}{ Protein mean $\mathbf{( g})^{\star}$} & \multicolumn{2}{l}{ Iron mean $\mathbf{( m g / 1 0 0 g})^{\star}$} & Iron mean & bio accessibility $^{\star}$ \\
\hline $5 \mathrm{~N}$ & $3.75^{\mathrm{a}}$ & $1 \mathrm{~N}$ & $9.15^{\mathrm{a}}$ & $6 \mathrm{OFSP}$ & $31.1^{\mathrm{a}}$ \\
$6 \mathrm{OFSP}$ & $3.70^{\mathrm{a}}$ & $3 \mathrm{~B}$ & $9.07^{\mathrm{a}}$ & $5 \mathrm{~N}$ & $26.7^{\mathrm{b}}$ \\
$7 \mathrm{~B}$ & $3.48^{\mathrm{a}}$ & $2 \mathrm{~N}$ & $6.06^{\mathrm{b}}$ & $7 \mathrm{~B}$ & $25.6^{\mathrm{b}}$ \\
$1 \mathrm{~N}$ & $3.44^{\mathrm{a}}$ & $4 \mathrm{~B}$ & $5.84^{\mathrm{b}}$ & $8 \mathrm{E}$ & $12.3^{\mathrm{c}}$ \\
$3 \mathrm{~B}$ & $3.34^{\mathrm{a}}$ & $8 \mathrm{E}$ & $3.53^{\mathrm{c}}$ & $2 \mathrm{~N}$ & $12.2^{\mathrm{c}}$ \\
$8 \mathrm{E}$ & $3.01^{\mathrm{a}}$ & $5 \mathrm{~N}$ & $1.86^{\mathrm{a}}$ & $4 \mathrm{~B}$ & $11.1^{\mathrm{cd}}$ \\
$4 \mathrm{~B}$ & $2.79^{\mathrm{a}}$ & $6 \mathrm{OFSP}$ & $1.57^{\mathrm{a}}$ & $1 \mathrm{~N}$ & $7.92^{\mathrm{de}}$ \\
$2 \mathrm{~N}$ & $2.77^{\mathrm{a}}$ & $7 \mathrm{~B}$ & $1.51^{\mathrm{d}}$ & $3 \mathrm{~B}$ & $7.42^{\mathrm{e}}$ \\
$\mathrm{p} \leq 0.05$ & & & & & \\
\hline
\end{tabular}

*Means in the same column with the same superscripts are not significantly different

mean percentage of iron bio-accessibility at $p \leq 0.05$ with grand mean of $16.8 \%$ and LSD of 2.158 .

Table 4 show that mean the protein content between modified food recipes was not significant different at $\mathrm{p}<0.05$. The mean iron bioaccessibility ranged from 7.42 to $31.1 \%$ and there was significant different within their mean at $\mathrm{p} \leq 0.05$. Recipe 6OFSP had high mean bioaccessibility of $31.1 \%$ followed by recipe $5 \mathrm{~N}(26.7 \%)$ and $7 \mathrm{~B}(25.6 \%)$.

\section{Iron and Protein Contents in the Consumption Size of $250 \mathrm{~g}$ and $500 \mathrm{~g}$ for Children Aged 6-23 months}

In this assessment the assumption was that a child will be able to consume $250 \mathrm{~g}$ to $500 \mathrm{~g}$ of the modified recipes per day. The intake of iron from the modified foods ranged from 37.8 to $229 \%$ RDA iron and 75.3 to $458 \%$ RDA iron at consumption levels of $250 \mathrm{~g} /$ day and $500 \mathrm{~g} /$ day, respectively. The percent of protein intake with consumption size of $250 \mathrm{~g}$ ranged from 53.1 to $72.8 \mathrm{RDA}$ protein and $106-46 \%$ RDA protein with consumption size of $500 \mathrm{~g} /$ day. Dry red kidney beans, onion, tomatoes, amaranths and bitter tomatoes, contributed significant iron content, respectively in recipe $1 \mathrm{~N}$ at $\mathrm{p} \leq 0.05$. For iron recipe $1 \mathrm{~N}, 2 \mathrm{~N}, 3 \mathrm{~B}, 4 \mathrm{~B}$ and $8 \mathrm{E}$ meets the $\mathrm{RDA}$ by more than $100 \%$ by consuming $500 \mathrm{~g} /$ day, while by consuming $250 \mathrm{~g} /$ day only recipe $1 \mathrm{~N}, 2 \mathrm{~N}, 3 \mathrm{~B}$ and $4 \mathrm{~B}$ will meet the

RDA for iron. However, for breastfed child all recipes will still meet the RDA fro iron and protein (Table 5).

Recommended Daily Allowances (RDA) for iron and protein in $100 \mathrm{~g}$ ranged from $15.1-91.5 \%$ and $21.2-29.1 \%$, respectively (Figure1).

\section{DISCUSSION}

The study analysed for raw food ingredients and the modified recipes. This helped to understand, which food is a good source of iron and/or protein. From the raw ingredients, fresh red kidney beans showed to have high amount of iron when compared to the dry ones. This result does not differ much with the study conducted in Tanzania by Mamiro et al., 2012 they found that the levels of iron in fresh bean grains were significantly higher than the average amount found in dry bean grains (Fe $5.6-8.0 \mathrm{mg} / 100 \mathrm{~g}$ ) (Mamiro et al., 2012). The higher iron content in fresh bean grain might be due to the presence of ferritin in fresh seeds which are also loaded in leaves (Ayala-Vela et al., 2008). Therefore consumption of fresh red kidney bean is recommended to enhance iron intake.

The results show that red kidney beans, pumpkin leaves and amaranths had high content of iron and contributed significantly iron content in recipes. It is therefore these ingredients are recommended for preparation of complementary foods to enhance iron intake. Onion, tomatoes and bitter tomatoes are regarded as spice only and not as nutrient source, in this study they contributed significant iron content in recipes. Therefore consumption of these spices sholud be encouranged for iron source. Only recipe $8 \mathrm{E}$ had egg as animal source of protein and iron. Raw egg showed high content of iron although in the recipe contributed less in recipe $8 \mathrm{E}$. Groundnuts were a good source of protein. Similar results were reported in a study conducted in Nigeria which recommended that groundnuts are good source of protein for human diet, animal feeds, and an antidote for children suffering from malnutrition (Ayoola et al., 2012). Red kidney beans were also good source of iron and protein. This study agrees with other study conducted in India which showed that red kidney beans are a good source of iron and protein, they analysed for raw and blanched (processed) red kidney beans (Chaudhary and Sharma, 2013). Also in Nigeria they analysed for roasted and boiled red kidney beans and found the same results (Olanipekun et al., 2015).

Recipe $1 \mathrm{~N}$ and $3 \mathrm{~B}$ are recommended for iron and protein intake, since they showed high content in both iron and protein. Both recipes had dry red kidney beans, amaranths, palm oil, salt, onion, tomatoes, and bitter tomatoes as ingredients except the first had 'nshakala' and the later had 'bira' banana variety. However, recipe $5 \mathrm{~N}$ had slightly high protein content compared to recipe $1 \mathrm{~N}$ and $3 \mathrm{~B}$.

Fermentation improves the bioavailability of minerals such as iron and zinc as a result of phytic acid hydrolysis (Temesgen, 2013). Fermentation has positive effect on 
168 Afr. J. Food Sci. Technol.

Table 5. Percentage RDA if 250g and 500g Consumed Per Day by a Child Aged Between 6 to 12 months and 12 to 23 months Respectively.

\begin{tabular}{lllll}
\hline Modified food recipe & \multicolumn{3}{c}{ Iron } & Protein \\
\cline { 2 - 4 } & \%RDA in 250g & \%RDA in 500g & \%RDA if 250g eaten/day & \% RDA if 500g eaten/day \\
\hline Banana puree: (1N) & 228.7 & 457.5 & 66.2 & 132.3 \\
Banana puree: $(2 \mathrm{~N})$ & 151.5 & 302.9 & 53.1 & 106.2 \\
Banana puree: $(3 \mathrm{~B})$ & 226.8 & 453.6 & 64.3 & 128.6 \\
Banana puree: (4B) & 145.9 & 291.9 & 53.8 & 107.6 \\
Katogo: $(5 \mathrm{~N})$ & 46.4 & 92.9 & 72.8 & 145.6 \\
Porridge: $(6 \mathrm{OFSP})$ & 39.3 & 78.7 & 71.2 & 142.4 \\
Porridge: $(7 \mathrm{~B})$ & 37.7 & 75.3 & 66.9 & 133.7 \\
Porridge: $(8 \mathrm{E})$ & 88.3 & 176.6 & 58.0 & 115.9 \\
\hline
\end{tabular}

$\mathrm{SD}=\mathrm{Standard}$ deviation

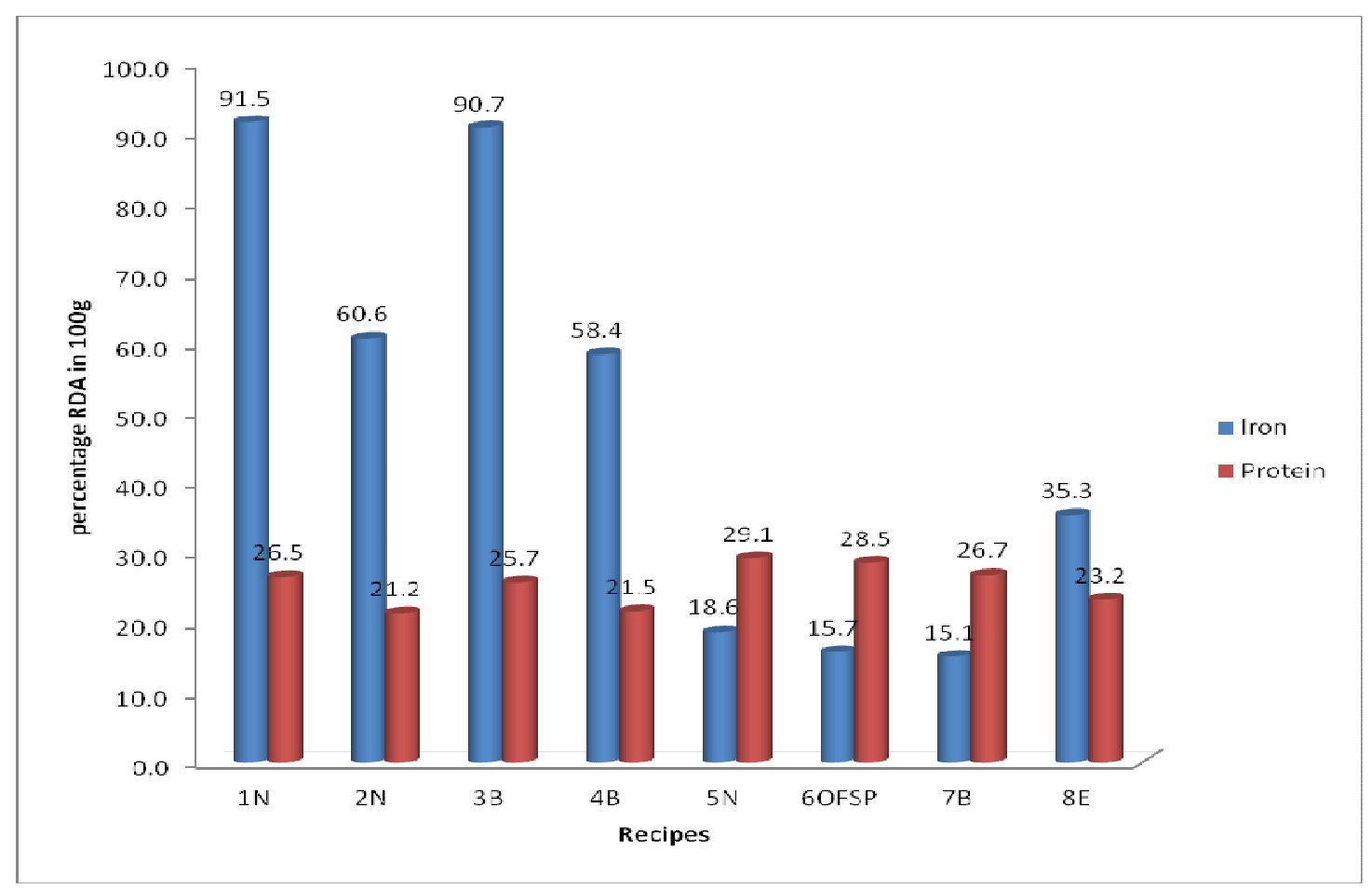

Figure1. Percentage RDA for Iron and Protein in 100g for Children Aged 6-23 months (ingredients per recipes are given in Table 1) 
protein content (Temesgen, 2013). Fermented food recipes showed higher bioaccessibility of iron compared to unfermented one for example banana purée recipe $(1 \mathrm{~N})$ had $9.1 \mathrm{mg} / 100 \mathrm{~g}$ with bioaccessibility of $7.9 \%$ while fermented porridge recipe (6OFSP) had $1.6 \mathrm{mg} / 100 \mathrm{~g}$ with bioaccessibility of $31.1 \%$. The high bioaccessibility percentage in fermented porridge recipe (6OFSP) might be due to; orange-fleshed sweet potato which is rich in vitamin $C$ (ascorbic acid) and beta-carotene, vitamin $C$ is a known enhancer of iron uptake and other studies indicates that B-carotene improve iron bioavailability (Christides and Sharp, 2013; García-Casal, 2006; Hurrell and Egli, 2010). Also vitamin C concentrations are positively associated with the ferritin (iron) values (Andre et al., 2015). Furthermore, fermentation increases the amount and bioavailability of iron and protein in cereals. It has also positive effect on protein content (Temesgen, 2013). The assumption is that iron bioaccessibility in fermented porridge (6OFSP) might have been contributed by vitamin $\mathrm{C}$, beta-carotene and fermentation process. Therefore, sweet potato-based porridge is recomended for complementary foods, since has better iron bioavailability.

It is concluded that porridge recipe with fermented maize flour, orange fleshed sweet potatoes, and groundnut flour is recommended for high iron intake since has better iron (31.1\%) followed by katogo with 'nshakala', pumpkin, groundnut flour, onion, tomatoes, bitter tomatoes (26.7\%) and porridge with fermented maize, 'bira' and groundnut flour $(25.6 \%)$. In the study area fermentation of maize flour for porridge is not common, therefore it should be promoted.

Bio accessibility of iron was not associated with iron content in the modified recipes, for example; recipe 6OFSP had moderate iron content but with high bioaccessibility compared to recipe $1 \mathrm{~N}$ with high iron content. This means food with high iron content does not mean will be $100 \%$ bio accessible. It is therefore to translate iron requirements into recommendations for daily iron dietary intakes requires an estimation of iron bioavailability.

With the average breast milk intake, the daily requirement of complementary food for children aged 623 months is $500 \mathrm{~g}$ per day and 600 to $674 \mathrm{ml}$ of breast milk consumed in a day (Arbeit and Kouevi, 2013; Dewey et al., 2006). Moreover, a breastfed child aged 6-9 months and 9-24 months is recommended to eat 2-3 and 3-4 meals per day respectively, while all non-breastfed children 6-23 months are advised to eat 4-5 times a day (Berti et al., 2014; WHO, 2010). The amount of protein required to satisfy a child daily nutritional requirement is $9.1 \mathrm{~g} /$ day for $6-8$ months, $9.6 \mathrm{~g} /$ day for $9-11$ months, and $10.9 \mathrm{~g} /$ day for $12-23$ months (Dewey et al., 2006). Breast milk provides a significant portion of daily protein requirement for children. When average breast-milk intake is assumed, the amount of protein needed from complementary foods is $1.9 \mathrm{~g} /$ day at $6-8$ months $(21 \%)$,
$4.0 \mathrm{~g} /$ day at $9-11$ months $(42 \%)$, and $6.2 \mathrm{~g} /$ day $(57 \%)$ at 12-23 months (Dewey, 2001; Dewey et al., 2006). Thus if the child will consume $250 \mathrm{~g}$ or $500 \mathrm{~g}$ of the modified recipes per day; protein intake will be 6.92 to $13.9 \mathrm{~g} /$ day or 9.47 to $18.9 \mathrm{~g} /$ day, respectively per child. From this point of view the child will consume RDA protein from 63 to $207 \%$ in the modified recipes which is more than what is needed from the complementary food. However, this does not consider bioaccessibility.

As stated earlier, the child will get some nutrients from breast milk making the complementary food to contribute significant amount of nutrients. However, other studies have reported that a food can be labelled as the 'source' of a nutrient when $100 \mathrm{~g}$ of the product presents more than $15 \%$ of the dietary reference intake (DRI) for the desired nutrient (Carvalho et al., 2012). The modified diet had more than 15\% RDA for iron and protein, therefore the modified diets are recommended for iron and protein intake to meet RDA for children aged 6 to 23 months.

\section{CONCLUSION}

Egg is a good source of iron followed by fresh and dry red kidney bean. Groundnut and dry red kidney bean showed to be good source of protein. Banana had the lowest iron and protein content. Dry red kidney beans, was the main source of iron in recipe $1 \mathrm{~N}$ which had higher iron content than other diets. Recipe $5 \mathrm{~N}$ had higher protein content with groundnut as the main source of protein in the recipe. Fermented porridge recipes had more bioaccessible iron than in banana recipes. Thus cereal fermentation and food diversity (mixture orangefleshed sweet potato, fermented maize flour, groundnut flour, sugar) would contribute significant to the bio accessibiliy of iron in recipes. Therefore to enhance intake of iron and protein in the diet; consumption of eggs, red kidney beans, groundnut and food diversity should be given priority. The developed and improved recipes have great potential of contributing substantially to iron and protein needs of children 6-23 months.

\section{ACKNOWLEDGEMENTS}

The authors acknowledged Sokoine University of Agriculture, Tanzania for technical support and Bioversity International for funding the study. Support from the Ministry of Agriculture, Tanzania Local Government Authority, Bukoba Rural District Council of Kagera region, farmers and participants are well acknowledged.

\section{REFERENCES}

Amagloh FK, Coad J (2014). Orange-Fleshed Sweet Potato-Based Infant Food is a Better Source of Dietary Vitamin A than a Maize- 
Legume Blend as Complementary Food. Food and Nutrition bulletin. 35(1): 51-59.

Andre CM, Evers D, Ziebel J, Guignard C, Hausman JF, Bonierbale M, Zum Felde T, Burgos G (2015). In Vitro Bioaccessibility and Bioavailability of Iron from Potatoes with Varying Vitamin C, Carotenoid, and Phenolic Concentrations. J. Agric. Food. Chem. 63(41) : 9012-21.

Arbeit B, Kouevi K (2013). A Study on Moringa Oleifera Leaves as a Supplement to West African Weaning Foods. Humburg University of Applied Science, West Africa.

Ayala-Vela J, Guía-González M, Espinosa-Huerta E, Acosta-Gallegos JA, Guzmán-Maldonado SH, Mora-Avilés, MA (2008). Iron Content and Ferritin Gene Expression in Common Bean (Phaseolus vulgaris L.). Agricultura Técnica en México. 34(4).

Ayoola P, Adeyeye A, Onawumi O (2012). Chemical Evaluation of Food Value of Groundnut (Arachi hypogaea) seeds. American J. Food and Nutr. 2(3): 55-57.

Bailey RL, West JrKP, Black RE (2015). The Epidemiology of Global Micronutrient Deficiencies. Annals of Nutrition and Metabolism. 66(2): 22-33.

Berhanu G, Mesfin A, Kebebu A, Whiting SJ, Henry CJ (2014). Household Food Processing Methods to Enhance Iron and Zinc Bioavailability in Modified Haricot Bean and Maize Complementary Food. Afr. J. Food Sci. 8(4): 190-195.

Berti C, Faber M, Smuts C (2014). Prevention and Control of Micronutrient Deficiencies in Developing Countries: Current Perspectives. Nutrition and Dietary Supplements. 6: 41-57.

Carvalho LM, Corrêa MM, Pereira EJ, Nutti MR, Carvalho JL, Ribeiro EM, Freitas SC (2012). Iron and Zinc Retention in Common Beans (Phaseolus vulgaris L.) After Home Cooking. Food and Nutrition Research. 56.

Chaudhary R, Sharma S (2013). Conventional Nutrients and Antioxdants in Red Kidney Beans (Phaseolus vulgaris L.): An Explorative and Product Development Endeavour. Food Sci. and Tech.14(2): 285-275.

Christides T, Sharp P (2013). Sugars Increase Non-heme Iron Bioavailability in Human Epithelial Intestinal and Liver Cells. PLoS ONE . 8: e83031.

Christides T, Amagloh FK, Coad J (2015). Iron Bioavailability and Provitamin A from Sweet Potato-and Cereal-Based Complementary Foods. Foods. 4(3): 463-476.

Detzel P. Wieser S (2015). Food Fortification for Addressing Iron Deficiency in Filipino Children: Benefits and Cost-effectiveness. Annals of Nutrition and Metabolism. 66(2): 35-42.

Dewey K (2001). Nutrition, Growth, and Complementary Feeding of the Brestfed Infant. Pediatric Clinics of North America. 48(1): 87-104.

Dewey K, Cohen R, Arimond M, Ruel M (2006). Developing and Validating Simple Indicators of Complementary Food Intake and Nutrient Density for Breastfed Children in Developing Countries.

Etcheverry P, Grusak MA, Fleige LE (2012). Application of in Vitro Bioaccessibility and Bioavailability Methods for Calcium, Carotenoids, Folate, Iron, Magnesium, Polyphenols, Zinc, and Vitamins B6, B12, D, and E. Frontiers in physiology.

García-Casal, MN (2006). Carotenoids Increase Iron Absorption from Cereal-based Food in the Human. Nutr. Res. 26: 340-344.

Gautam S, Platel K, Srinivasan K (2010). Influence of $\beta$-carotene-rich Vegetables on the Bioaccessibility of Zinc and Iron from Food Grains. Food chem. 122(3): 668-672.

Gibson RS, Hotz C (2001). Dietary Diversification/modification Strategies to Enhance Micronutrient Content and Bioavailability of Diets in Developing Countries. British J. Nutr. 85(S2): S159-S166.

Hurrell R, Egli I (2010). Iron Bioavailability and Dietary Reference Values. Am. J. Clin. Nutr. 91(5): 1461S-1467S.

Kennedy G, Razes M, Ballard T Dop MC (2010). Dietary Diversity: A Simple Tool for Developing and Evaluating Food and Nutrition Security Interventions. Food-base Approaches for Improving Diets and Raising Level of Nutrition. In I. S. FAO (Ed.). Rome 7-9 December.

Kinabo J, Mnkeni AP, Nyaruhucha CNM, Msuya J, Haug A, Ishengoma $J$ (2006). Feeding Frequency and Nutrient Content of Foods Commonly Consumed in the Iringa and Morogoro Regions in Tanzania. Inter. J. Food Sci. and Nutr. 57(1-2): 9-17
Klein, S (2012). Protein-Energy Malnutrition, in Goldman's Cecil Medicine (Twenty Fourth Edition).

Luten J., Crews H., Flynn A., Van Deal P., Kastenmayer P., Hurrell R.,Deelstra H., Shen L., Fairweather-Tait S., Hickson K., Farre R., Schlemmer U., Frohlich W. (1996) Interlaboratory Trial on the Determination of the In Vitro Dialysability from Food. J. Sci. Food Agric. 72:415-424.

Mamiro PM, Nyagaya M, Mamiro DP, Jumbe T, Ntwenya J, Bundara N (2012). Contribution of Minerals from Fresh Kidney Bean Leaves and Grains in Meals Consumed in East, South and Central Africa. Afr. J. Food Agric. Nutr. and Dev. 12(5): 6479-6489.

Mbela DEN, Kinabo J, Mwanri A, Ekesa B (2017). Modification of Local Diets to Improve Vitamin A, Iron and Protein Content for Children Aged 6 to 23 Months. Afr. J. Food Agric. Nutr. and Dev. (AJFAND)(17025), 22-in press

McClements D (2003). Analysis of Protein. University of Massachusetts Amherst.NBS (National Bureau of Statistics) and ICF Macro. (2011). Tanzania Demographic and Health Survey 2010. Dar es Salaam, Tanzania: NBS and ICF Macro. 451pp.

NBS (National Bureau of Statistics) and ICF Macro. (2016). Tanzania Demographic and Health Survey and Malaria Indicator Survey (TDHS-MIS) 2015-16. Dar es Salaam, Tanzania: NBS and ICF Macro.591pp

Olanipekun OT, Omenna EC, Olapade, OA, Suleiman P, Omodara OG (2015). Effect of Boiling and Roasting on the Nutrient Composition of Kidney Beans Seed Llours. J. Food Sci.4(2): 24-29.

Ruel MT, Bouis HE (2004). The Role of Food, Agricultural, Forestry and Fisheries in Human Nutrition. Food Modifications and Impact on Nutrition. International Food Policy Research Institute, Washington, DC, US

Saunders AV, Craig WJ, Baines SK (2012). Zinc and Vegetarian Diets. Medical J. Australia. 9(1-2): 17-21.

Soetan K, Oyewole O (2009). The Need for Adequate Processing to Reduce the Anti-nutritional Factors in Plants Used as Human Foods and Animal Feeds: A Review. Afr. J. Food Sci. 3(9): 223-232.

Temesgen M (2013). Nutritional Status of Ethiopian Weaning and Complementary Foods: A Review. scientificreports. 2(621).

Trumbo P, Yates AA, Schlicker S, Poos M (2001). Dietary Rreference Intakes: Vitamin A, Vitamin K, Arsenic, Boron, Chromium, Copper, lodine, Iron, Manganese, Molybdenum, Nickel, Silicon, Vanadium, and Zinc. Journal of the American Dietetic Association.101(3): 294301.

van Lieshout $M$, West CE, Permaesih D, Wang YXuX, Van Breemen RB, Lugtenburg J (2001). Bioefficacy of $\beta$-carotene Dissolved in Oil Studied in Children in Indonesia. The American J. Clin. Nutr. 73(5): 949-958.

WHO (2010). Partners. Indicators for Assessing Infant and Young Child Feeding Practices. Part 3: Country Profiles. World Health Organization 